\title{
Information provision and restriction: The roles of police, media and public in coverage of the Coral-Ellen Burrows murder inquiry
}

\section{AㅅBSIRIACI}

Six-year-old Coral-Ellen Burrows disappeared in September 2003 after her stepfather, Stephen Williams, had apparently dropped her off at school, though in fact he had murdered her. After extensive searches, her body was found 10 days later. Williams pleaded guilty to murder and was duly sentenced. The intensive cross-media coverage of the search for CoralEllen - of the kind that Innes (1999) commenting on media and police interactions in Britain calls 'blitz coverage', made this case the preeminent news story of 2003. However, the attenuated nature of the search also exposed some of the tensions inherent in the relationships between those parties interested in the case. We understand these to consist of six entities which have an existence that is both material and conceptual: these are the victim's family, possible suspects, the local community, the police, the media, and the national public, in this case envisaged in a dual role as wider community and media-audience. All of these stand in relationship to the more abstract yet rigid institution of the law, whose dictates guide the behaviour of the police, and strongly influence that of the media. This paper reports on research carried out by analysis of New Zealand Herald, Wairarapa Times-Age and TV One coverage of the case, and by two interviews with journalists investigating the forces that shaped the media coverage. 
$\mathrm{F}$ IOR 11 days in September 2003, the New Zealand national media gave intensive coverage to the search for a six-year-old girl, Coral-Ellen Burrows, who went missing between her home and school in Featherston, in the Wairarapa. Sadly, the search was not successful in finding her alive. By the end of the period, when her body was found hidden in vegetation on an isolated lakeshore, the search for a missing person had turned into a murder inquiry, with the child's stepfather, Stephen Williams, as the accused.

Media coverage of the Burrows case was of the type that British sociologist Martin Innes calls 'blitz coverage' (1999, p. 272) where there is sustained cross-media coverage over a number of days. In Britain such coverage is obtained by only 1 to 2 percent of murders that occur, and the situation in New Zealand is likely to be similar. In this case the coverage lasted for well over a year-even at the time of writing (April 2006) there are still occasional items relating to the aftermath of the investigation. The extended duration of interest in the incident was due to its positioning at the intersection of a number of contemporary social anxieties in New Zealand. For instance, Coral-Ellen's death was the latest in a series of murders of children by adults: an editorial in the local Wairarapa Times-Age on two weeks after she disappeared listed 10 others previously killed in the region alone (Wyatt, 2003). The violence that killed Coral-Ellen was also linked to her stepfather's methamphetamine addiction, something which is viewed as a growing social problem (Hoskins, 2003) and later the spotlight of criticism fell on the governmental support service for protecting children in inadequate living situations (Wairarapa Times-Age, 2003, October 29). The discursive transformations the coverage went through as it touched on these anxieties are worthy of study in themselves but on this occasion however our comment is limited to the ethical issues raised by the intense coverage the case attracted.

\section{Methodology}

The bulk of this coverage occurred in the last quarter of 2003, in two distinct periods. The first was the 11-day period, 9-19 September, during which the child was sought and her body found, and the second period was in mid December when Coral-Ellen's stepfather pleaded guilty in court and the underlying causes of her death were discussed. This article concentrates on the initial 11 days. Our methodology is based on content analysis of material from three main sources: news and feature coverage from the New Zealand 
Herald; news and current affairs coverage from the state broadcaster TV One from September 9-19, and a series of articles from the local newspaper, the Wairarapa Times-Age, plus some additional material from the New Zealand police website. We have analysed transcripts of the television coverage and copies of the newspaper articles. So far, as part of an ongoing research project, we have conducted interviews with two reporters: one each from TVOne and the Herald, who did the bulk of the coverage for their organisations: this material is included as indicative of directions for future research.

An interview with the police so far eludes us, but a recent Mediawatch programme on interactions between the police and media provides a limited insight into the police point-of-view.

First, we provide a brief account of early coverage and its relationship to relevant provisions of the Journalist Code of Ethics promulgated by the New Zealand Engineering, Printing and Manufacturing Union and the Television Code of Broadcasting Practice (2004). We then consider the six main parties to a typical murder case, focusing on the interests of three of them: the police, the media and the national public.

\section{Reporting the search for Coral-Ellen Burrows}

The first public notification of the search for Coral-Ellen was given in a 50second television news item on the night of September 9. This was a brief item of the kind typically broadcast when a child goes missing. By early next day the New Zealand Herald was posting what quickly became an iconic photo of Coral-Ellen, which, cropped to remove her from her family context, became the emblem of her innocence and beauty of nature. By that afternoon the search had a name, Operation Reef, with a senior officer, Detective Inspector Rod Drew, in charge. A straightforward missing child search would not normally have such a senior person in charge within 24 hours-so there was an implication from the start that the police suspected foul play.

The Police News release at 9.34 next morning still stated that CoralEllen had been dropped at school by her stepfather and announced a free phone number for public information. Three hours later it was revealed that her schoolbag had been found in a waterway upstream from her school, suggesting that she had not gone there under her own steam.

By $1.51 \mathrm{pm}$ next day, the television news coverage has developed a different tone. The bulletin was devoted to what the newsreader called 'an impassioned plea' from separated father Ron Burrows of Te Puke, speaking 
for himself and Coral-Ellen's mother, Jeanna Cremen. He said: 'We miss her, we want her back ... Coral is someone special for all her family, her brother, aunts, uncles, cousins and grandparents.' One person was not mentioned in this list - the other adult Coral-Ellen shared a house with, and who had taken her to school-her stepfather Williams. At this point, despite strong statements from the police that they had no suspect in Coral-Ellen's disappearance we, and probably many other viewers, began to read between the lines. The coverage of the case began to take on an odd, elliptical texture where what was said, as a TVOne reporter stated in a report on September 9, was not necessarily what people were thinking.

For instance, as spokesperson for the police, Detective Inspector Rod Drew would be present and communicative at some times, providing information and asking amiably for public assistance, yet at other times he was minimally co-operative with the media. On one notable occasion on September 11 when asked by a reporter exactly where some items of clothing had been found he replied three times with increasing firmness of tone 'I don't want to elaborate on them right now'. At other times, information would be presented that was paradoxical in its implications and therefore could not easily be reconciled in the reader or viewer's mind. For example, while One News reported on September 12 that Coral-Ellen's stepfather, Williams, had appeared in court on a charge of assaulting her uncle, the police asserted that the charge was 'unrelated' to the case, a statement that was true only in a narrow and contingent sense. A particular vortex of confusion operated around the identity and number of Lada vehicles possessed by people of interest in the case: the Cremen/Williams family was known to possess one but D.I. Drew refused to confirm it was connected with the case, whereas commonsense, which later turned into hindsight when it was revealed that Williams had also used a second, very similar car, indicated that it was indeed relevant to CoralEllen's disappearance.

The Wairarapa Times-Age, embedded in the community in which the search was taking place, had readier access to local comment, both attributed and unattributed, than the metropolitan and national sources. By Thursday, September 11, it was reporting that Coral-Ellen had run away from school in the past while noting that her stepfather had admitted to having had a disagreement with Coral-Ellen about her going to school. The next day the newspaper featured a claim from a neighbour that the Cremen/Williams 
household had been connected with drug dealing and relayed comments from both Williams' mother and 'sources close to the family' that he had been in hospital the previous day with 'stress-related' illness (Wairarapa Times-Age, 2003, September 12). Nevertheless, the Times-Age also refrained from shaping what it called 'a round of rumour and speculation' into any distinct pattern (September 13). By September 16 was still reporting police statements that Wiliiams' 'unrelated' status in regard to the investigation was unchanged but it did so in parallel with accounts from 'Featherston sources' that Williams had been soaking wet when he arrived home on the day of Coral-Ellen's disappearance and that 'someone' had been sold bleach by a Featherston supermarket owner on that same Tuesday (September 16).

\section{A distinctive genre of communication}

It was instances of mystifying communication like these that sparked our interest in coverage of the case. They led us to note that police/media/public interaction around crime is a distinctive genre of communication. The police have an unusual degree of access to the media during a high-profile case-in the case of television they appear to speak directly to the public, to camera, often live, bypassing much of the processing that goes in a normal news bulletin. Moreover in such cases they appear sometimes to suspend immediate and full truth-telling in favour of a deferred public good: the capture and successful prosecution of the offender. As we will show, this approach to the mediation of police activities is understandable as a result of the complex legal circumstances that impinge on the police, where they wish to use the media as a resource to solve crime without providing information in such a way as to prejudice a later trial. However, we were interested in the placing of those police tactics within the news institution-news being a genre, we assumed, significantly involved with accuracy and truth. This assumption on our part is supported by the first of the 10 prescriptions in the New Zealand Journalist Code of Ethics:

a) They shall report and interpret the news with scrupulous honesty by striving to disclose all essential facts and by not suppressing relevant, available facts or by distorting or improper emphasis.

Another prescription from this code we consider particularly relevant to this case is: 
j) They shall do their utmost to correct any published or broadcast information found to be harmfully inaccurate.

Similarly, the behaviour of television and radio journalists is influenced by their employers who are required by the Broadcasting Act to develop codes of ethics that ensure inter alia 'Fair and accurate programmes and procedures for correcting factual errors and redressing unfairness' (s.21 (e) (iii) 1989). Furthermore the Television Code of Broadcasting Practice General Programme Standards requires broadcasters to be 'truthful and accurate on points of fact' (Code of Practice, 2004, p. 9). The Code of Practice also has a lengthy section explaining the obligation for broadcast journalists 'to work to the highest standards of accuracy, impartiality and objectivity' (pp. 49-51).

However, the achievement of scrupulous honesty and the highest standards of accuracy in reporting on some crime cases are clearly rendered difficult by the restricted amount of information made available to reporters by the police. Sometimes, as in the complex yet slow-moving Burrows case, the media are left reporting on confusion and uncertainty for extended periods, even if as we will see, experienced journalists are likely to have a strong personal sense of where the truth may lie. Nevertheless, in the environment of 'blitz'-style crime-reporting it appears that the police behave as they do with the tacit cooperation and endorsement of both the media and of the public. Both of these parties agree to be kept less than fully-informed in the interim, in order to support police aims, which are assumed, but not necessarily proven, to be closely aligned with the public interest.

We are not claiming that this structuring of collaboration around a future good is a heinous activity, but it is one that is both practically and ethically fascinating. It has possible implications for wider situations of communication between other authorities claiming to serve the public good, and the public themselves in another role as informed citizens.

Why the assumptions and practices that guide police and media interaction are significant is related to the implicit presence of notions of 'public interest' which assume the people are better able to be good citizens when they are accurately informed. However the common expressions 'public interest' and 'public good' which are generally used as synonyms, are rarely defined outside the academic literature (eg. Iggers, 1999). By no means do all journalistic codes even mention the public interest (for instance, National Press 
Photographers Association, 2004; National Union of Journalists, 1994; Society of Professional Journalists, 1996; New Zealand Journalist Code, 2005). Where these term and broader terms such as 'general welfare' and 'public responsibilities' are used, they are generally explained by means of a list of activities that are stated or implied to promote the public goal, for instance National Union of Journalists, 2001; Press Complaints Commission, 2004; Knight Foundation, 2005; Gannett, 1999; Media Alliance, 2005; American Society of Newspaper Editors, 2002. However, these lists are quite diverse, as a comparison of the examples in Appendix 1 illustrates.

\section{Interested parties in crime coverage}

The unusual texture of the Coral-Ellen Burrows media coverage, which obfuscated almost as much as it elucidated, and thus made it difficult for the media to ensure that the public were accurately informed, was the result of the interaction of the length of the inquiry with the actions of each of the six main parties to a typical murder case. At the beginning of this project we understood those parties to be: possible suspects, the victim's family, the local community, the national community or 'public', the police and the media. The interests of these parties sometimes conflict both with each other and with societal goals including justice and reduction in crime. We will discuss the first three in a cursory manner only and elaborate on relationships between the others.

Possible suspects include the actual offender, who typically does not wish to be caught. However it is important that innocent people are not convicted and the criminal justice system must try to prevent this by employing scrupulous and fair processes. The restriction of information about details of the crime can both help to locate the perpetrator and also prevent suspicion falling on those who are innocent. The victim's family typically wish the offender to be apprehended but sometimes know or suspect that the perpetrator is a family member and wish to protect him or her. The local community: local people want information from the police and media which will tell them what is going on and assist them to direct their efforts to help the victim's family. They also want to feel safe themselves. However, in the process of such an investigation other aspects of the community become open to scrutiny and the town's reputation can suffer. For instance, an editorial column in the Wairarapa TimesAge on September 20 described the Burrows case as an occasion on which Featherston's 'grubby secrets' had become public, including the fact that it had 
a 'criminal underclass'. This public comment was seen as undermining efforts to improve Featherston and led to a community petition demanding retraction of the editorial as well as to the withdrawal of advertising by at least one local business (Wairarapa Times-Age, 2003, September 23; Marshall, 2003)

The final three interested parties - the police, media, and national public - require greater consideration. We will discuss them using insights gained from Martin Innes' (1998) work on the British police/media relationship and Judy McGregor (1993), Cate Brett (2000) and Jim Tully's (Mediawatch, 2005) observations of the police relationship with the media in New Zealand.

\section{Police}

The police are under constant pressure to solve crimes as rapidly as possible although they are selective about which crimes to investigate. Murder is viewed as the worst of crimes. It is a rare crime in New Zealand and around 90 percent of murderers are caught. The pressure on police is greatest in high profile murder cases especially when a child victim, or possible victim, is involved. Nevertheless, there are restrictions on the means available to the police in working on even on such important cases. First, there are restrictions due to shortage of resources. Police rely on high-profile media coverage to bring increased resources, both from internal funding and from the public, including information (hence the Hotlines, with their easy-toremember 0800 numbers) and volunteers to assist with searches. Second, there are restrictions on the kinds of things they can do. Commentators agree that police can and do put immense pressure on suspects, including using the media to project images and information which make perpetrators feel hunted and remorseful. However, there are limitations on this pressure, including bans on the use of excessive physical force and psychological torture.

The police constantly seek to manage the flow of information around a case to elicit desired responses from their superior officers, from potential witnesses and from suspects. They sometimes withhold key aspects of a case from the media or give them out on a confidential basis. This might include details of the cause of death (which are rarely revealed in detail in advance of the trial), or of the crime scene, or crucial incriminating evidence such as that the perpetrator appears to be left-handed. Sometimes information is given to selected, trusted journalists and not to others: this practice acts as a control on unauthorized media activity.

Unless journalists have sufficient resources do their own research in 
parallel to the police these practices restrict the strength of their coverage since they can report only what they know to be the case. The acceptance of information on a confidential basis can also be at odds with the provision that journalists should not suppress relevant and available facts.

The head of journalism at Canterbury University, Jim Tully, spoke about this issue on a Mediawatch programme broadcast on Radio New Zealand's National programme. The following comments were made in relation to the then-current coverage of the murder of a German back-packer in the Taranaki region- rather than to the earlier Burrows case - but they are a further indication of the ingoing significance of these issues.

Well, the police will always think strategically in terms of how they release information. Sometimes they release or give the impression that they have much more information than they actually have, that might be designed to make the alleged offender complacent or careless. On other occasions of course, they might, through the media, give the impression that they know more or the case is further advanced than it actually is in order to put pressure on the alleged offender so that they might do something silly or get rattled (Mediawatch, 9 October 2005).

This analysis of the relationship is confirmed by former D.I. Graham Bell who hints at problems with this symbiotic relationship if it is not well- managed;

It is a very close relationship that exists and police officers have traditionally used the media - well that's a bad term - but the available media resources are very important to an investigating officer, particularly in a high profile crime like that and there have been occasions in recent years when I think that the media have gone a little overboard, especially in the face of an extremely cooperative police officer in charge of the case (Mediawatch, 9 October 2005).

The police also need to think about preserving evidence for a future trial, whether it be physical evidence or the testimonies of witnesses, from being tainted by those outside the inquiry, including the media. Furthermore, there is a concern that heavy and sensational media coverage may prejudice the 
chances of a suspect obtaining a fair trial. The Public Issues Committee of the Auckland District Law Society discussed this issue in a 1986 report on police and media interdependence:

[...] a vital aspect is the 'hardening effect' that concentrated news coverage may bring towards one or more members of the community who may come under suspicion even thought they have not been brought to trial, ... The very degree of news media attention may result in an insidiously real detriment to someone to whom the law imputes innocence, but who may nevertheless be 'convicted' before the public. In lay terms, the phenomenon is labelled 'trial by the media' (1986, p. 4).

In the Burrows case all these pre-existing strictures on the police relationship with the media interacted to some degree, along with specific personality factors. The Wellington Regional Police Media Manager Kay Calder was assigned to the inquiry along with Detective Inspector Drew and together, according to accounts from the journalists from the Herald and TVOne, they ran a professional but very tight ship, holding a daily press conference over the search period. DI Drew had a pre-existing reputation for discretion that he reinforced on this case. Unless he wanted public help he released as little discursive, speculative information as possible: to the extent that one of the Herald's reporters wrote a colour-piece about him as a man you would not bet against in poker (2003, September 15). However, Calder and Drew's handling of the media was evaluated differently by the two lead reporters. The newspaper reporter was impressed by the straightness of Drew's delivery:

Herald: $[\mathrm{He}]$ didn't try to get tricky, he didn't hesitate, he would either answer the question or tell you he wasn't prepared to answer that question or it wasn't appropriate to answer that question at that time.

By contrast, the television reporter was frustrated by the same approach:

TVOne: As far as I am concerned the Police were very, very closed mouthed and quite hard to deal with on this case, it was one of the hardest channels of communication that I've done and it was very 
frustrating for journalists, and we felt we were being kept in the dark and then refusing to answer questions.

From even these brief quotes we can see that the interests of the media and the police conflict as well as coincide on such high-profile cases. It is also suggested that the configuration of these interests affects different journalists differently: a situation that we find to be explained by the different working conditions of the broadcast and print media. It is to the description of media interests we now turn. We note however that both journalists discussed their awareness of the ethical standards of the organisations for which they worked. The Herald reporter specifically referenced the New Zealand J ournalist Code of Ethics whereas the television reporter, while citing the TVNZ Code of Practice, also emphasized the internalization of a personal ethical code, of treating others as you would wish to be treated.

\section{Media and the commodification of crime news}

The media is a series of businesses, each aiming to maximize profits, while glossing that situation with a rhetoric of serving community interest: a gloss which does have some basis in fact. Nevertheless a discourse of commodification of media information is often engaged in by academic commentators (see Jewkes, 2004). The media are said to treat people and their hopes, fears, triumphs and tragedies as no more than 'stories' or material for narrative products which boost sales and thereby advertising revenue by appealing to the (presumably depraved) interests and tastes of consumers: readers and viewers (see Iggers, 1999; Jewkes, 2004). Yet, it would be inaccurate to say that the media coverage of the Coral-Ellen Burrows case did no more than commodify the people involved. The family received tremendous public sympathy and support, including material support. Furthermore, media publicity may well have been a factor in inducing Williams to confess.

Nevertheless, the value of crime stories as commodities is high here in New Zealand as elsewhere. Crime news is easy to obtain for media organisations and relatively cheap to source since police do most of the research. Newspaper editor Cate Brett has asserted that it has traditionally suited the news media to cultivate strong police sources which can render a constant flow of authoritative news sources without the need for time consuming and costly independent checking (2001, p. 24). Crime news is also popular with audiences. A 1993 study by McGregor found that coverage of crime 
comprised 16.4 percent of hard news coverage in the five NZ metropolitan daily newspapers. The Herald reporter indicated his paper alone was regularly selling 10,000 extra copies a day during the inquiry, around a 5 percent increase on its regular readership.

However, the length of time during which media can engage in such lucrative blitz coverage is usually severely limited by New Zealand's legal restrictions on reporting of criminal cases. Unlike the American system where, as Tully and others note, comment on the merits of a case is allowed even while a trial is taking place, here such comment is allowed only until an arrest is made. At that point there are restrictions on what can be reported in order to protect the right of suspects to a fair trial. This period before charges are laid provides what Tully speaks of as a 'window of opportunity' for journalists;

The [Dominion] Post has done what it is able to do and which many media organisations also do-it has taken advantage of a window of opportunity between the committing of an offence and the point at which somebody is arrested or an arrest is imminent. That's the time when you can do some enterprise reporting. Once somebody is arrested you're closed down because it becomes sub judice. (Mediawatch, 9 October 2005).

The window of opportunity on this case was untypically large, since, for the first nine days of the case Williams was never mentioned as a suspect, creating a loophole for the media to publish details of his record, which consisted of around 90 convictions. They also felt free to drop increasingly broad hints that he was suspected of being complicit in Coral-Ellen's disappearance.

In the face of police denials that there were significant links between CoralEllen's disappearance and Williams, both journalists said that their research and coverage were guided by a combination of intuition and experience: what they both called 'gut feeling'. From the first day the TVOne journalist, who had previously worked on the Teresa Cormack case, a case involving a kidnapped and murdered child, thought that Coral-Ellen was dead and that the stepfather was responsible. The Herald reporter worked on a similar assumption after meeting Williams on the first day and finding his behaviour very strange in the circumstances. He described the methods he used to create copy that built on his assumptions and deductions - pushing the limits of implication. 
Herald: I think I just decided for myself that it didn't matter what he [Drew] said - that they were connected, I just treated it as if they were. [...] as far as I was concerned this was a homicide enquiry pretty quickly. Mr Drew had told us, 'yesterday their stepfather joined the search but, according to a relative got too upset and left' and I quoted him as saying, 'He feels like he's to blame'. And I just left it at that — which you could read two ways, which is how I intended it.

Q. You intended it that way-so what do you call that kind of writing?

Herald: Being smart. I think it's giving the public what they need-it's giving them the clue and, okay, you're dancing on the point of defamation but 'he feels like he's to blame'. Well he could feel like he's to blame 'cos he dropped her off and he didn't check that she got into the class safely but you could read more into that if you wanted to and I knew that people would. But what the heck? I'll write my story, I'll get my quotes and I'll file them up to Auckland and they make their decisions about whether they think I'm pushing the boundaries too far and I think that there were times when they thought I was and took stuff out.

The television journalist also felt that although aware of the legal restrictions imposed by media law, it was important to go to the limits of those restrictions, on the assumption that if anything was defamatory or sub judice it would be caught by the subeditors. Both journalists therefore relied on back-up supervision to ensure their compliance with ethical and legal codes of conduct. Indeed, TVNZ considers what it calls 'referring upwards' to be so important a management technique that it is the first item in its Code of Broadcasting Practice (2004).

While both journalists spoke of the need to independently check facts, the pressured, technologically-dependent, multi-deadline nature of television news gathering meant that resources for parallel research into the facts of the case were more limited for TVOne in the early stages. By contrast, subject to only one deadline a day, the newspaper reporter saw himself as conducting an investigation alongside that of the police,

Herald: Oh I'm VERY pleased if I find out stuff, not so much that they may not know but they're not telling us or that the readers don't know. I'm there to serve the readers. [...] Yeah, there's always an amateur detective in all of us - we all want to solve the case and yeah, so you're 
going for it 'cos it's a big mystery.

Specifically, he was satisfied with having found out that Williams had borrowed a neighbour's Lada car after having abandoned a similar car he had previously used (although this was a fact which the television reporter had also discovered) and furthermore, of establishing that Williams had bought petrol on the day of the disappearance in order to burn evidence from the car in which he had attacked Coral-Ellen.

These behaviours are evidence of journalists striving to fulfill their responsibilities to make facts available as implied in the relevant sections of their respective codes of conduct. However this is also risky behaviour based on possible inaccuracy and the danger of contaminating evidence. Because Williams confessed and pleaded guilty, the issue of how far the media had 'pushed the boundaries' was not put to the test in this case. It is interesting to speculate however to what extent a defence lawyer might subsequently have been able to cast doubt on the ability of the jury to come to an unbiased decision.

Note also that not all journalists are union members and subject to this code. However, we imagine that the principles are generally accepted since, even though it is an in-house document, the TVNZ Code of Practice is mandatory reading for all its journalists.

\section{The interests of the national public}

We now move on to consider the third major party involved - the national public. As we noted earlier, several other jurisdictions' Codes of Ethics, such as various American and British codes, place the public interest at the top of the list of obligations.

For instance, the American Society of Newspaper Editors Code states: 'The primary purpose of gathering and distributing news and opinion is to serve the general welfare by informing the people and enabling them to make judgments on the issues of the time' (American Society of Newspaper Editors, 1975)

By contrast the New Zealand Journalist Code of Ethics is silent on the issue of public interest and, as a result, the national public are on the receiving end of this intricate dance between the police and media, fact and opinion. They, conceived of as an abstraction, are the ones whose good is supposedly, ultimately, being served by this system, but in practice they are the most scantily imagined 
and infrequently discussed party to this situation. As the commercial pressure exerted on the Wairarapa Times Age to apologise for having editorialised that Featherston was home to a 'criminal underclass' indicates, the goals of the local public and the wider national public are obviously not always identical. Feeling less immediately threatened than those who live in the vicinity of the crime, the national public may want to hear a greater quantity of disturbing information and even to appreciate watching the suffering of others not closely related to them. In addition, the public's desire to know as many details of a crime and the progress of the investigation as possible may conflict with the success of the investigation (even though the public wants that, too) because of the police need to manage information. Moreover a crime which proves to be one in a series - as Coral-Ellen's murder eventually came to be categorized as one in a series of fatal child-abuse cases - can also reflect on aspects of national identity as community representatives discuss the reasons, including a widespread cultural culpability, for the existence of such a trend.

In that sense the national public, if imagined largely in the role of media consumers, may serve as a motivator for increased amounts of speculative and sensational coverage, thereby enticing journalists, as employees of commercial organisations, towards the limits of ethical behaviour in coverage.

However, the national public is also not one and the same group as the corpus of media-users, especially when media users are imagined as fragmented into sub-groups loyal to a particular channel or publication's news. Rather, there is an overarching national public interest in feeling safe and protected by the efficient operation of the police/media nexus around crime solving. Yet, there is also a national public interest in simultaneously retaining a critical distance on police/media behaviour, so that the merits of particular procedures and assumptions can be questioned. It is this aspect of the public interest, the non-commercial and civic, that is not well-served by the narrativised, speculative and nebulous coverage of this kind of large event.

In theorizing a broader view of similar conflicts, Mark Sagoff (1981) makes a distinction between 'consumer and citizen preferences'. Consumer preference is personal and self-interested. It is typically measured in 'willingness to pay' and used in cost-benefit analysis. Citizen preference however, has nothing to do with the price of goods in the marketplace. It involves principled decisions on matters of public policy, such as the laws on abortion and euthanasia or protection of endangered species. Just after the peak of 
coverage of the Burrows case the Office of the Commissioner for Children, in a report on the murders of two other Wairarapa children, Saliel and Olympia Aplin (2003), published recommendations that the media give particular 'care and consideration' to instances of violence against children, in protection of the dignity both of victims and of their surviving siblings. This assertion of principle failed to gain traction however in the face of the immediate appeal of the investigative and story-telling aspects of these and subsequent cases.

That there may be a narrowness of media understandings of the public interest in New Zealand is suggested in descriptions of the journalists' understandings of their role. For instance, the broadcast journalist is selfdescribed as a surrogate presence for the individual viewer.

TV One: We are there to tell our viewers the story, to tell what is happening in the search for this little girl, that's what we are there for, what are they doing to find her, where could she be? That's our role, eyes and ears.

The newspaper journalist outlines two models of media/public relationship: one, a commercial model, describes a similar provision of information for consumers deemed to have purchased the right to access it

Herald: You're doing it for the readers of the Herald - people that pay their dollar. They're paying, they want as much information as you can possibly give them so yeah, they're your audience and the bosses know that too - the sales of their newspaper is going up because of these big stories you're writing so they're not going to complain. How pure is the relationship between news and fact? Are they one and the same thing? Well I'd hope so, you're not—accuracy is the first rule so yeah, you've got to be right.

The second model is an intriguing one: it proposes that the attraction of such coverage for newspaper readers is to participate in a game, where the goal is to figure out for one's self what has actually happened,

Herald: [...] one of the reasons that I thought that this case became such a cause célébre in the public mind was actually because those limitations 
on naming him [Williams] or identifying potential suspects meant that people were even more inclined to, they wanted to read the newspaper, they wanted to read every word, they wanted to rake over the whole thing, to work it out for themselves. Everyone likes to play detective, as I said before, not just the reporters out in the field and a lot of the time you play detective by watching the TV news, listening to the radio and reading the newspaper or maybe reading two or three newspapers - can you get all those different strands and you pull it together.

If this proposition holds true then crime-news coverage may indeed be an entertainment - not so much in the sense of passive voyeurism or in the temporary transcendence of everyday consciousness provided by undemanding leisure activities, but in a more interactive mode in which active mental work provides a sense of satisfaction as the media consumer seeks to create a resolved understanding out of the partial factual knowledge provided by the police/media information nexus. Whatever it might be however, this kind of entertainment serves the public interest only in a tangential sense: it may be a source of personal gratification, but it is not a reliable resource to use as the material for informed public debate.

\section{Conclusion}

There are not many local stories in the New Zealand news media as large, worthy and involving as this one, the most widely-followed news-story of 2003. However, because of the competitive, commercial environment of contemporary media publication, newspaper and television editors will always welcome more stories with the wide public appeal of this tragic search for a lost child.

Nevertheless stories like this also provide situations where the ethical tensions inherent in the practice of journalism come under obvious pressure and where questions about the priorities of the rights and interests of various parties to the various legal and communicative processes.

For example, we note that in this case the relationship between recommended codes of ethics and actual behaviour from media professionals was somewhat loose. When police restrict information provision, reporters work from intuition and supposition as well as their own research. As a result information may be presented to the public in a coded form that is difficult to perceive as fact. Furthermore, the relationship between media and police and the extent to which that relationship is determined by a shared concept of the 
public interest is unclear. On the evidence of their mission statement the New Zealand police (About us, 2005) seem to have a much stronger, more explicit sense of the public interest than the New Zealand media. The mission statement explicitly identifies: crime prevention, keeping members of the community safe and bringing people to justice as being in the public interest. On the other hand, on the evidence we have so far, the media concept of the public interest is more varied and there is thus a limited consensus from which to operate. Users of media are characterised as consumers, or subscribers, or vicarious game players, or as wanting to be entertained and titillated, but there is little attention paid to a concept of informed citizenship through media. Specifically neither the EPMU Journalist Code of Ethics nor the TVNZ Handbook contains reference to the public interest, as similar codes in other countries do.

In any situation where there is more than one variable involved it is difficult to balance competing interests. For instance, currently in New Zealand, as exemplified by the Coral-Ellen Burrows case, we can't maximize for both a fair trial for a suspect and full information for the public. In such complex ethical situations one of two routes is usually followed. Either a system of ordering of priorities is developed in which it is declared that in murky situations a particular interest will always be ranked as most important - in the New Zealand situation this highest priority appears to be the right of a suspect to a fair trial.

The other option is to try and balance all the competing interests so that everybody gets a little of what they value. In practice, in the light of the somewhat minimalist codes of ethical codes followed by New Zealand journalists, as exemplified by the New Zealand Journalist and TVNZ Codes, this seems to be the strategy followed by the journalists to whom we spoke.

Our project thus far is indicative only since we have dealt with a very small sample of informants: we wish to talk to other journalists and editorial staff, and of course to the police, but we think our initial intuition that there are ethical issues inherent in this kind of extended, yet restricted, coverage is correct, and warrants further exploration. Specifically, in relation to the communicative environment around the reporting of the Burrows case, two questions present themselves. Are we happy to have the rights of the suspect take priority over a concept of public interest and do we need a stronger and more explicit concept of the public interest that would guide the behaviour of both the media and the police? 


\section{References}

Documents

Amalgamated Engineering Printing and Manufacturing Union, New Zealand Rules, Section 42: Journalist Code of Ethics, 2005. (Retrieved 19 April 2006): www.epmu.org.nz/SITE_Default/about/rules/finance.asp

American Society of Newspaper Editors, ASNE Statement of Principles (2002). (Retrieved 19 April 2006): www.asne.org/index.cfm?id=888

Auckland District Law Society (1986, March 25) Reporting criminal enquiries-the balance between freedom of speech and the interests of justice. Auckland, NZ: Report by the Society's Public Issues Committee.

Brett, C. (2001) Control of the crime story: free speech vs fair trial. Christchurch, NZ: University of Canterbury.

Chief Reporter (2003, September 20) Tough on Featherston. Wairarapa Times-Age. (Retrieved 13 August 2004):http://times-age.co.nz/news

Comment on Featherston a 'kick in the guts', says mayor (2003, September 23). Wairarapa Times-Age. (Retrieved 13 August 2004): http://times-age.co.nz/news

Coral's bag found (2003, September 11). Wairarapa Times-Age. (Retrieved 13 August 2004): http://times-age.co.nz/news

CYF agrees to call inquiry Wednesday (2003, October 29). Wairarapa Times-Age. (Retrieved 13 August 2004): http://times-age.co.nz/news

Every parent's nightmare (2003, September 13). Wairarapa Times-Age. (Retrieved 13 August 2004):http://times-age.co.nz/news

Gannett Newspaper Division Principles of Ethical Conduct (1999). (Retrieved 19 April 2006): www.asne.org/ideas/codes/gannettcompany.htm

Hoskins, S (2003, September, 23) Police want help in fight against P. Wairarapa Times-Age. (Retrieved 13 August 2004): http://times-age.co.nz/news

Iggers, J. (1999). Good news, bad news: journalism ethics and the public interest. Boulder, CO: Westview Press.

Innes, M. (1999). The media as an investigative resource in murder enquiries. British Journal of Criminology, 39 (2): pp. 269-286.

Jewkes, Y. (2004). Media and crime. Thousand Oaks, CA: Sage Publications.

Knight Foundation (2005). News in the Public Interest. (Retrieved 19 April 2006): www.knightfdn.org/default.asp?story=journalism/public.asp

McGregor, J. (1993). Crime news as prime news in New Zealand's metropolitan press. Auckland, NZ: Legal Research Foundation, No 36.

Marshall, C. (2003, September 27). Featherston has its say. Wairarapa Times-Age. (Retrieved 13 August 2004): http://times-age.co.nz/news

Media Alliance Code of Ethics (Australia) (n.d.). (Retrieved 19 April 2006): www.alliance.org.au/hot/ethicscode.htm

National Press Photographers Association (US) Code of Ethics (2004). (Retrieved 19 April 2006): www.nppa.org/professional_development/business_practices/ ethics.htm

National Union of Journalists (UK) (2006). The public interest. (Retrieved 19 April 2006):. www.nuj.org.uk/inner:php?docid $=224$ 
National Union of Journalists (UK), Code of Conduct (1994, revised 2001). (Retrieved 19 April 2006): www.uta.fi/ethicnet/uk.html

New Zealand Amalgamated Engineering Printing and Manufacturing Union. New Zealand Journalist Code of Ethics (n.d.). (Retrieved 19 April 2006): www.epmu.org.nz/SITE_Default/about/rules/finance.asp

New Zealand Herald (2003, September 9-19) Series of news reports and features on search for Coral-Ellen Burrows.

New Zealand Police: About Us (2005). (Retrieved 19 April 2006): www.police.govt.nz/about/

New Zealand Police News (2003, September 9-19).

Office of the Commissioner for Children (2003). Report on the investigation into the deaths of Saliel Jalessa Aplin and Olympia Marissa Aplin. Wellington, NZ.

Police say Coral dead or abducted (2003, 16 September). Wairarapa Times-Age. (Retrieved 13 August 2004): http://times-age.co.nz/news

Police impound two vehicles (2003, September 12). Wairarapa Times-Age. (Retrieved 13 August 2004): http://times-age.co.nz/news

Sagoff, M. (1981). At the shrine of Our Lady of Fatima, or why political questions are not all economic. Arizona Law Review. 23 (11981): pp. 1283-1298, reprinted in Louis P.Pojman, (Ed.) (2001) Environmental Ethics. Belmont, CA: Wadsworth (pp. 467-473).

Society of Professional Journalists (US), Code of Ethics (1996). (Retrieved 19 April 2006): www.spj.org/ethics_code.asp

Television New Zealand Archive (2003 September 9-19) Coral Burrows: series of 52 broadcast items. TV One, Television New Zealand: Auckland, New Zealand.

Wyatt, A. (2003, September 27). Featherston revisited. Wairarapa Times-Age. (Retrieved 13 August 2004): http://times-age.co.nz/news

\section{Interviews}

National Radio (2005, October 9). Mediawatch: Programme about Crime Reporting, Radio New Zealand.

New Zealand Herald journalist (2005, September 6). Personal interview with Ann Hardy.

Television New Zealand journalist (2005, April 26). Personal interview with Ann Hardy.

\section{Appendix: Statements on the public interest}

National Union of Journalists (UK)

1.The public interest includes:

a) Detecting or exposing crime or a serious misdemeanour

b) Protecting public health and safety

c) Preventing the public from being misled by some statement or action of an individual or organisation

d) Exposing misuse of public funds or other forms of corruption by public bodies 
e) Revealing potential conflicts of interest by those in positions of power and influence

f) Exposing corporate greed

g) Exposing hypocritical behaviour by those holding high office

2.There is a public interest in the freedom of expression itself.

3. In cases involving children, journalists must demonstrate an exceptional public interest to over-ride the normally paramount interests of the child.

\section{Gannett Newspaper Division Principles of Ethical Conduct}

Serving the public interest

- We will uphold First Amendment principles to serve the democratic process.

- We will be vigilant watchdogs of government and institutions that affect the public.

- We will provide the news and information that people need to function as effective citizens.

- We will seek solutions as well as expose problems and wrongdoing.

- We will provide a public forum for diverse people and views.

- We will reflect and encourage understanding of the diverse segments of our community.

- We will provide editorial and community leadership.

- We will seek to promote understanding of complex issues.

Knight Foundation, 'News in the Public Interest'(2005)

What is news in the public interest? It is the news good citizens need to run their government and their lives. It includes:

- Engaging local, state, national and international government news;

- Explanatory journalism about public policy trends;

- Investigative journalism about abuse of power in all levels of society;

- Journalism about how and why the news media do what they do.

Alastair Gunn is an associate professor in the Department of Philosophy at Waikato University and his specialist field is ethics. Ann Hardy is a senior lecturer in the Department of Screen and Media Studies at Waikato and her specialist field is media and religion. She is a former radio and television journalist. An earlier version of this article was presented to the Journalism Education Association of New Zealand (JEANZ) Conference 2005 at Wintec, Hamilton, New Zealand, on December 7-8.

a.hardy@waikato.ac.nz 